\title{
Positive global environmental impacts of the COVID-19 pandemic lockdown: a review
}

\author{
Hong Chuan Loh • Irene Looi - Alan Swee Hock Ch'ng • Khang Wen Goh • \\ Long Chiau Ming $\cdot$ Kean Hua Ang
}

Accepted: 16 July 2021 / Published online: 23 July 2021

(C) The Author(s), under exclusive licence to Springer Nature B.V. 2021

\begin{abstract}
Global environmental change is mainly due to human behaviours and is a major threat to sustainability. Despite all the health and economic consequences, the impact of the COVID-19 pandemic lockdown on environmental health warrants the scientific community's attention. Thus, this article examined and narratively reviewed the impact of several drastic measures taken on the macro environment and holistic planetary health. We note that the amount of pollution in the air, water, soil, and noise showed a significant decline during the pandemic. Global air quality improved due to lower
\end{abstract}

H. C. Loh · I. Looi · A. S. H. Ch'ng

Clinical Research Centre, Hospital Seberang Jaya,

Ministry of Health Malaysia, 13700 Seberang Jaya,

Penang, Malaysia

e-mail: lohhongchuan@gmail.com

I. Looi

e-mail: irenelooi@yahoo.com

A. S. H. Ch'ng

e-mail: alanchng@yahoo.com

I. Looi · A. S. H. Ch'ng

Medical Department, Hospital Seberang Jaya, Ministry of

Health Malaysia, 13700 Seberang Jaya,

Penang, Malaysia

K. W. Goh

School of Computing, Faculty of Computing and

Engineering, Quest International University, 30250 Ipoh,

Perak, Malaysia

e-mail: khangwen.goh@qiup.edu.my anthropogenic emissions of air pollutants and atmospheric particles. Water ecosystems also demonstrated signs of recuperation in many countries. Less commercial fishing internationally resulted in the restoration of some aquatic life. Additionally, significant reduction of solid and water waste led to less soil pollution. Some places experienced cleaner beaches and ocean water while wildlife sightings in urban areas across the world occurred more often. Lastly, the COVID-19 pandemic lockdown also led to a worldwide decline in noise pollution. However, the beneficial environmental effects will not be permanent as

\footnotetext{
L. C. Ming

PAP Rashidah Sa'adatul Bolkiah Institute of Health Sciences, Universiti Brunei Darussalam, Gadong, Brunei Darussalam e-mail: longchiauming@gmail.com

K. H. Ang ( $\square)$

School of Biological Sciences, Faculty of Integrated Life Sciences, Quest International University, 30250 Ipoh, Perak, Malaysia

e-mail: keanhua.ang@qiup.edu.my
} 
the world gradually returns to its pre-pandemic status quo. Therefore, behavioural changes such as adopting a lifestyle that reduces carbon footprint are needed to make a positive impact on the environment. In addition, world leaders should consider the national policy changes necessary to ensure continuity of as many of the positive environmental impacts from the COVID-19 pandemic lockdown as possible. Those changes would also serve to lessen the likelihood of another zoonotic calamity.

Keywords COVID-19 - Pandemic - Lockdown ·

Pollution $\cdot$ Environmental health

\section{Introduction}

Coronavirus disease-2019 (COVID-19) is now considered one of the world's greatest challenges and biggest catastrophes since World War II (Gautam, 2020b). As of today, 12 July 2021, there are nearly 200 million people infected with the virus and over 4 million deaths worldwide. Unfortunately, these numbers are still on the rise.

While the COVID-19 pandemic continues to ravage both the health and economy of nations around the world, we are also contending with one of the greatest crises in human history, i.e., global environmental change. The change is mainly due to human behaviours and is a major threat to over half of the world's population. Unfortunately, the world's poorest communities, those with the least responsibility for producing environmental decay, are the most affected (Fust, 2010). If the human population continues to contribute to climate change, rising global temperatures and more natural disasters will plague the world. We would likely encounter more flooding and more droughts with rising sea levels and higher temperatures (Huckelba \& Van Lange, 2020). Climate scientists have estimated that the Arctic Ocean will be free of ice by the summer of 2050 (Screen \& Deser, 2019). As the ice melts, ancient viruses and bacteria from the permafrost soils that are potentially harmful to human beings may be released (Tsangaras \& Greenwood, 2018). This could cause more outbreaks of infectious diseases in addition to the diseases of zoonotic origin that we are already experiencing.
To date, there have been several studies regarding the environmental impact of the COVID-19 pandemic. Helm et al. presented a comprehensive research agenda from the environmental and economics perspective with five sets of research questions including (1) the short-term effects, (2) the longer-term economic effects and some of their potential environmental effects, (3) deglobalisation, trade and environmental effects, (4) environmental aspects of intergenerational equity, the balance sheet approach, and natural capital, and (5) the permanent effects on behavioural shifts (Helm, 2020). Another article provided four underlying research clusters based on a systematic content analysis of the studies, namely (1) COVID-19 and environmental degradation, (2) COVID-19 and air pollution, (3) COVID-19 and climate or meteorological influences, and (4) COVID19 and temperature (Shakil et al., 2020). LopezFeldman et al. provided an insight on air pollution exposure from the COVID-19 pandemic (LópezFeldman et al., 2021). There was also a review that focused on the negative impact of the pandemic on socio-economic factors and the positive environmental impact on air and water quality (Saadat et al., 2020). Straka et al. discussed improved air quality during the pandemic in the United States (Straka et al., 2021). Another study which examined the effect of meteorological factors on COVID-19 health outcomes reported that high temperature and high humidity minimise the transmission of COVID-19 but when the temperature, wind speed, dew or frost point, precipitation, and surface pressure are low, the transmission is enhanced (Sarkodie \& Owusu, 2020). In the literature on the subject that we reviewed, there was no comprehensive narrative summarizing the positive environmental impacts of the COVID-19 pandemic lockdown globally.

Naturally, there has been a lot of research on COVID-19 and most of it has been focused rightly on the negative impact of the pandemic. Disease, death, and economic devastation certainly warrant such attention. However, even though the outbreak has adversely altered the everyday lives of millions of people around the world since its onset, there have also been some benefits. With a non-normative approach, this paper considers various unexpected positive aspects of the COVID-19 pandemic lockdown on planetary health. Even if we will not continue "lockdowns" after the COVID-19 pandemic abates, 
the positive environmental impacts we witnessed during the pandemic show that it is still possible to make great and rapid positive change. This fact should persuade citizens and governments around the world who doubt that we can or should act in environmental and climate change matters that it is necessary, urgent and, above all, possible to effect change. For the sake of all life on earth, authorities everywhere must press for new policies that will address global environmental change including climate change, environmental degradation, and the looming threat of more zoonotic pandemics. The objective of this paper is to identify many of the positive environmental changes that occurred during the COVID-19 pandemic and point to those as examples for policymakers and citizens around the world to show that it is still possible to make great and rapid positive change.

\section{Materials and methods}

In this paper, we discussed the positive impacts of the COVID-19 pandemic lockdown on four environmental domains: air, water, soil, and noise. The positive effects were defined as reduction of air pollutants; improved water quality and increases in aquatic life; reduction of solid waste, wastewater and sewage sludge; and decreases in noise pollution. We searched through two major citation databases, namely PubMed, and Google Scholar using the terms 'COVID-19 pandemic', 'environment', 'air', 'water', 'soil', 'noise', 'aquatic life', 'land use', 'wildlife', 'zoonotic disease' for articles dated between 1st January 2020 and 1st February 2021. We also used reverse-forward citation (hand searches) from the included studies to search for relevant studies. We limited our search to English language articles only.

\section{Environmental impacts of the COVID-19 pandemic lockdown}

The outbreak of COVID-19 was declared a pandemic by the World Health Organization (WHO) on 11th March 2020 (Mitra et al., 2020). Quarantine, isolation, and lockdown measures were implemented in much of the world as per public health epidemiology practices in order to mitigate human-to-human transmission of COVID-19 (Shah et al., 2020). The measures taken by countries to tackle this crisis have led to an enormous economic meltdown and disruptions in social behavioural patterns (Hart \& Halden, 2020). However, this once-in-a-century phenomenon paradoxically resulted in some positive impacts on planetary health. By taking into account the impact of industry shutdowns, lockdowns, and travel bans, there were multiple environmental benefits from the COVID-19 outbreak, primarily due to less anthropogenic pollution.

Air quality and atmospheric particles

According to the WHO, 4.6 million people die annually from diseases and illnesses directly linked to unhealthy air quality (Cohen et al., 2017). Air pollution has been known to be associated with a major prevalence of respiratory diseases such as pneumonia, chronic obstructive pulmonary disease, asthma, and others (Van Donkelaar et al., 2010). Air pollutants such as nitrogen dioxide $\left(\mathrm{NO}_{2}\right)$, sulphur dioxide $\left(\mathrm{SO}_{2}\right)$, and particulate matter $2.5\left(\mathrm{PM}_{2.5}\right)$ are present in our atmosphere in alarming amounts and data show more people are dying each year due to bad air quality. Before the pandemic, in the period between 2016 and 2018, nearly 10,000 additional premature deaths in the US were associated with the increase in $\mathrm{PM}_{2.5}$. For the year 2016, these deaths, apart from the tragedy they represent, also resulted in $\$ 89$ billion in economic damages (Clay \& Muller, 2019). The 2019 World Air Quality Report showed that South Korea was among 37 member countries of the Organisation for Economic Co-operation and Development with the highest $\mathrm{PM}_{2.5}$ level in the air. In China, $98 \%$ of the cities surpassed the targets established by WHO guidelines. Of the top 30 most polluted cities, 21 are located in India while five are located in Pakistan (IQAir, 2019).

During the COVID-19 pandemic, many places across the globe implemented lockdown measures. The mobility index report based on Google tracking data from February to April 2020 across the region that includes Spain, Italy and France showed a reduction of up to $90 \%$ in mobility (Muhammad et al., 2020). There were travel restrictions for tourism, entertainment, and personal purposes. The restrictions caused many flights to be grounded resulting in a significant lessening of emissions since planes are known for their intensive use of fossil fuels. Industrial production decreased and there was a reduction in the use of 
vehicles, both of which lowered demand for oil and reduced extraction and refining activity. The world also saw a decline in coal consumption by power plants. While several studies found an increase in ozone levels during the pandemic (Grange et al., 2020; Huang et al., 2021; Lovrić et al., 2021), overall, the unprecedented circumstances of the pandemic lockdown brought about a major reduction in air pollution, resulting in positive effects concerning air quality worldwide (Lenzen et al., 2020).

Globally, atmospheric emissions were reduced by $0.6 \mathrm{Mt}$ of $\mathrm{PM}_{2.5}$, and 5.1 Mt of $\mathrm{SO}_{2}$ and $\mathrm{NO}_{2}$. It is noteworthy that in the 32-year history of intergovernmental climate policy, none of the attempts by any government or any international agreement has had such a drastic mitigation impact on air pollution (Lenzen et al., 2020). Data collected on the level of concentration of aerosol optical depth (AOD) by Moderate Resolution Imaging Spectroradiometer onboard National Aeronautics and Space Administration's (NASA) satellites indicated a massive reduction by $50 \%$ of AOD in the India region's air quality. This is due to the substantial change in aerosol levels, the lowest in 20 years, because of COVID-19 lockdowns in India (Gautam, 2020b). The pandemic also exerted a major downward effect on China's energy consumption and air pollutant emissions (Wang \& Su, 2020). During the quarantine in China, there was a significant reduction in $\mathrm{NO}_{2}$ concentrations based on data collected by the TROPOspheric Monitoring Instrument onboard the Copernicus Sentinel-5 Precursor satellite. The ozone monitoring instrument aboard the NASA Aura spacecraft also reported similar atmospheric changes. There was as much as $30 \% \mathrm{NO}_{2}$ emission reduction just in Central China (Dutheil et al., 2020). A similar trend was also observed with emissions of carbon dioxide $\left(\mathrm{CO}_{2}\right)$ associated with the use of fossil fuels like coal and crude oils. The $\mathrm{CO}_{2}$ emissions decreased by $18.7 \%$ (182 $\mathrm{Mt} \mathrm{CO}_{2}$ ) compared to the first quarter in 2019, including decreases of $12.2 \%\left(92 \mathrm{Mt} \mathrm{CO}_{2}\right)$ in the industrial sector, $61.9 \%$ $\left(62 \mathrm{Mt} \mathrm{CO}_{2}\right)$ in transport, and $23.9 \%\left(28 \mathrm{Mt} \mathrm{CO}_{2}\right)$ in construction (Wang et al., 2020). Some data showed that there was a reduction of nearly 1 million tons of carbon emissions during the lockdown, which is equivalent to $6 \%$ of global emissions. The $\mathrm{PM}_{2.5}$ index in China across 367 cities also showed a reduction of $18.9 \mu \mathrm{g} / \mathrm{m}^{3}$ (Zambrano-Monserrate et al., 2020). In Turkey, the $\mathrm{PM}_{2.5}$ index was reduced by $34.5 \%$ by the end of April 2020 (Aydın et al., 2020). According to the European Space Agency (ESA) and NASA, European countries such as Spain, Italy, and, France as well as the US also showed a 20-30\% reduction of $\mathrm{NO}_{2}$ during the pandemic (Gautam, 2020a).

The enduring global COVID-19 pandemic lockdown is revealing the direct link between the level of air pollution and the amount of economic activity, including manufacturing, transportation, energy generation, etc. This suggests that in order to fight air pollution, a renewable and green energy-based system will be required and should be widely adopted whenever possible in all areas, particularly at industrial sites. For instance, encouragement from governments, including tax reduction, subsidies, or monetary rewards to encourage the use of solar panels and windmills for both the residential and industrial sectors. This pandemic also provides an excellent chance for us to study and invent ways to monitor urban traffic and transportation in order to cut fuel consumption and maintain a healthy environment. Reduced road travel and fewer air flights throughout the world resulted in a significant reduction in fuel use. One way to maintain reduced road travel is to encourage public transit. Travelling via public transit consumes less energy and causes less pollution than travelling by private vehicles. In addition, providing financial incentives to promote the use of electric vehicles or bike riding are also pivotal steps towards a greener environment.

Water quality and aquatic life

Air pollutants in the atmosphere could cause nutrient pollution in waterways as well. For instance, $\mathrm{NO}_{2}$ can react with other chemicals to form acid rain, which specifically causes harm to freshwater ecosystems including streams, rivers, lakes, and watersheds. Water acidification, along with the concomitant reduction in acid neutralization capacity, has led to deleterious changes in water quality (Akimoto, 2003; Clair \& Hindar, 2005). With regards to the air pollution reduction mentioned earlier, there would be an expected reduction in acid rain formation thereby producing higher availability of freshwater globally.

Water ecosystems showed signs of recuperation in many parts of the world during the pandemic. There 
was an improvement in the water quality of the Ganga River, the 'National River' of India, during the lockdown especially around industrial clusters and urban areas. The effect could be seen in terms of increased dissolved oxygen and decreased biological oxygen demand, faecal coliform, total coliform, and nitrate concentration. With improved water quality, the river's self-cleaning properties were enhanced. Typically, there are vast quantities of effluent from domestic and industrial wastewater that reach the river untreated or partially treated and this results in severe deterioration of water quality. Over the last two decades, several government programs cost the government millions of dollars without much success. During the lockdown period, there was a reduction of approximately 1300-1340 million litres per day of industrial wastewater. Other human activities like social and religious functions, waterways transport, fishing, and so forth were also prohibited, leading to less dumping of solid waste and less littering along its banks by residents and tourists. Recent research by the Indian Institute of Technology, Roorkee, showed that the water of the Ganga River became fit for drinking purposes during the pandemic. As defined by the Central Pollution Control Board, the river was listed as category "A" and its waters were classified as fit for drinking with conventional treatment (Dutta et al., 2020; Upadhyay, 2020). Improvement was also observed in the Yamuna River, near Delhi. Measurements of the dissolved oxygen in the river water were as high as about $5 \mathrm{mg} / \mathrm{L}$ during the pandemic. After two months of COVID-19 lockdown, the water in Venice, Italy, also appeared cleaner and aquatic life became more noticeable, something not seen in the city for many years. As the number of tourists dropped, activity on the waterways, sediment churning, and other causes of water pollution dropped substantially causing the waters in Venice's canals to be much cleaner compared to the time before COVID19 (Saadat et al., 2020).

Another unexpected environmental impact was observed in aquatic life. Due to the migratory nature of fishermen and the frequency of international visitors, it was feared that fishing communities and ports could potentially become hotspots for COVID19 infection (FAO, 2020). Therefore, many fisheries across the world experienced partial or complete shutdown resulting in a reduction of fishing activities during the pandemic. In addition to port shutdowns, there was a sharp decline in demand for seafood, loss of access to cold storage, and termination of shipping and air cargo services (Orlowski, 2020). The reduction in fishing and its related industries allowed marine ecosystems some time to recover. According to Dr. Rainer Froese of the GEOMAR Helmholtz Centre for Ocean Research in Germany, a decline in fishing caused by the pandemic would lead to a rise in fish biomass. European fish stocks such as whitefish, flatfish, and herring would nearly double their biomass if there were no fishing for one year. China also reported that tuna, which originally followed the Kuroshio Current to Japanese fishing grounds via the China Sea, appears to have stopped to feed in the China Sea (Korten, 2020). Furthermore, Carlos Quarte, research chair at the Red Sea Research Center in Saudi Arabia, stated that the pandemic accelerated the regeneration of fish populations allowing the Center to meet conservation targets faster. The COVID-19 pandemic lockdown was a de facto moratorium on heavily fished stocks which created an effect similar to the virtual cessation of commercial fishing during World Wars I and II.

There were also reports showing increases in sea mammals such as killer whales, dolphins, and seals in regions where they have not been seen in decades (Lombrana, 2020). In addition, endangered turtles are experiencing a resurgence. In Thailand, the nests for leatherback sea turtles are at their highest numbers in two decades. A similar trend was seen in Florida, US, with a significant increase of 76 leatherback sea turtle nests compared to 2019 (Geggel, 2020). The practices of pharmaceutical firms along with other overharvesting activities led to a decline in the number of horseshoe crabs over the decades. During the pandemic, there was a sign of recovery with hundreds of thousands of horseshoe crabs spawning on the shores of the Delaware Bay in the Eastern US. This in return assisted a rebound in red knot birds which rely on the eggs of the crabs for food (Nishan, 2020). A global mass coral bleaching has been occurring since 2014 due to global warming. During the pandemic, there were signs of rebound for the coral reef ecosystems. For instance, in Hawaii, there was an increase in the coral reef especially among baby corals when compared to 2019 (Tianna, 2020). Both the reduction in fisheries activities and the restoration of aquatic life during the pandemic may have caused a decline in the 
extraction of blue carbon that further reduced atmospheric $\mathrm{CO}_{2}$ emissions (Mariani et al., 2020).

Although there have been some good environmental results from the COVID-19 pandemic lockdown, a few weeks or months will not be sufficient to undo or repair the environmental damage that has been done over many years. Governments need to build proper sewage treatment plants and ensure that businesses and industries dispose of their waste in accordance with strict rules and regulations, imposing heavy fines on violators. In the context of fisheries, better enforcement of national rules over fishing would likely improve fisheries management. International and regional agreements for the monitoring, control, and surveillance of local and international waters may help prevent overfishing. Researchers should also focus on action-oriented studies to identify the consequences of long-term food security as well as environmental and resource management implications of current fishing activities and seek alternatives for seafood-based food and other products.

Soil quality, land use, and wildlife sightings

The soil is an essential component of the ecosystem that regulates not only the surrounding environment but also affects water, climate, and food production (Mishra et al., 2020). Soil contamination from anthropogenic activities, specifically urbanisation, will reduce crop yield and its quality. It will also change soil organic matter and its biodiversity as well as the quality of groundwater (Singh \& Singh, 2020). During the pandemic, there were reports of a significant reduction of solid waste. A survey from Tunisia showed that $85 \%$ of respondents indicated positive changes in food waste prevention by setting up a strategy of saving, storing, and eating leftovers (Jribi et al., 2020). In Morocco, two cities, Khenifra and Tighassaline, showed a reduction in municipal solid waste in March 2020 compared to March 2019 (2572 tons versus 2456 tons; 136 tons versus 126 tons, respectively) (Ouhsine et al., 2020). In Shanghai, China, there was a reduction of approximately $23 \%$ in household waste (Fan et al., 2020). Solid waste from industrial and construction activities was also reduced during the crisis (Qarani \& Development, 2020).

Wastewater and sewage sludge contribute to soil pollution as well. Several reports indicated a decrease in municipal, industrial, commercial, and grey water waste during the pandemic. Increased green areas and lesser soil erosion were observed as well (Qarani \& Development, 2020). One study indicated that every $1 \%$ increase in urban vegetation would result in a $2.6 \%$ decrease in cumulative COVID-19 cases (You \& Pan, 2020). Moreover, a notable change in the appearance of many beaches across the world could be seen during the pandemic lockdown. Waste generated by tourists was significantly reduced resulting in beaches such as Acapulco in Mexico, Barcelona in Spain, and Salinas in Ecuador now looking cleaner with clearer waters (Zambrano-Monserrate et al., 2020). A survey from observations on Salinas, Manta, and Galápagos beaches indicated that the lockdown also led to a temporary improvement of environmental conditions similar to marine protected areas. Approximately 45\% of the Respondents agreed that the beaches are cleaner with lesser plastic (Ormaza-González \& CastroRodas, 2020). As stated earlier, better air and water quality result in less acid contamination of the ground and thereby causing a drop in soil acidification. For all these reasons, soil contamination declined significantly and this led to improved soil quality.

There was also a surge in wildlife sightings during the COVID-19 pandemic lockdown, particularly in urban environments. These sightings included a wild puma in downtown Santiago, Chile, during a nighttime curfew, and a herd of plundering goats on the streets of Llandudno, Wales (Child, 2020). These incidences are mainly due to a significant reduction in human mobility during the crisis. The COVID-19 "anthropause" reduced the destructive effects of our increasingly expansive lifestyles on the movement of animals (Rutz et al., 2020). This phenomenon may provide some insights for further research to better understand how we might improve coexistence between humans and wildlife, particularly in designing a more sustainable and wildlife-friendly environment.

Consumer involvement is vital in reducing domestic waste and creating a healthier environment. Using eco-friendly products and implementing the concept of "reduce, reuse, and recycle" would have a big impact. Governments and businesses need to reduce deforestation and plant more trees to increase green areas and reduce soil erosion. On top of that, an increase in urban vegetation will help restore some balance in habitats that were destroyed during urbanization. Seeing a resurgence of some species and a 
return to certain habitats of others during the lockdown is a persuasive argument for better township planning and more protected areas and wildlife conservation zones. Finally, more research to gather data that can be used to develop better environmental regulations for wildlife is needed.

Reduction of noise pollution and impact on coinhabitants

Automobile traffic, ships on the sea, aircraft, industry, and other human activities are all sources of seismic noise. In order to flatten the contagion curve, the COVID-19 pandemic lockdown created a widespread reduction in human activity, leading to a months-long reduction of up to $50 \%$ in seismic noise. This is the longest and most prominent recorded reduction in global anthropogenic seismic noise throughout history (Lecocq et al., 2020).

One study found significant noise reduction in China in late January 2020 and then Italy, the whole of Europe, and the rest of the world between March and April 2020. The lockdown measures in mainland China contributed to a marked decrease of roughly 4-12 dB in cultural noise (seismic noise with frequencies above $1 \mathrm{~Hz}$ ). There was, on the other hand, a smaller decrease in seismic noise of around 1-6 dB in Italy after the country was locked down since traffic in Italy did not decrease as much as in China (Xiao et al., 2020). A 33\% reduction in seismic noise was found after a lockdown in Brussels, Belgium (Lecocq et al., 2020). In the City of Madrid, there was a reduction of 4 to $6 \mathrm{dBA}$ captured by the monitoring network during the lockdown (Asensio et al., 2020). In the island nation of Barbados in the Caribbean, due to a reduction in tourism, the seismic noise from March to April 2020 decreased by approximately $45 \%$ compared to observations made for the same period in 2019. A permanent seismic station in Sri Lanka indicated a reduction of nearly $50 \%$, the highest recorded since July 2013 (Lecocq et al., 2020). A study also showed that the pandemic lockdown led to a 5-10 dB reduction of the anthropogenic noise level in Shillong, India (Somala, 2020).

More than 200 million people around the world are affected by noise pollution (Mirzaei et al., 2012). Nearly $40 \%$ of the population in the countries of the European Union were subjected to road traffic noise with an equivalent sound pressure level of more than
$55 \mathrm{dBA}$. Most of those people live in areas that do not provide residents with acoustic comfort. In cities in developing countries, the noise pollution problem is also severe and is primarily caused by traffic-induced noise (Berglund et al., 1999). The Environmental Expert Council of Germany stated that the persistence of extreme irritation from noise over extended periods of time may lead to distress (Ising \& Kruppa, 2004). Many epidemiological studies in the past have identified the correlation between exposure to noise pollution and numerous medical conditions such as myocardial infarction, cardiovascular disease, hypertension, sleep disorders, psychiatric disorders, weakened immune systems, and birth defects (Geravandi et al., 2015). The COVID-19 pandemic lockdown had altered the soundscape and led to a significant reduction in noise pollution. This could result in fewer noise-induced health impairments.

Noise pollution is also a threat to animals with a considerable impact on communication, use of space, and their reproduction rate (Sordello et al., 2020). A research was conducted in the San Francisco Bay Area, before and after the recent state-wide confinement, to determine whether a common songbird (white-crowned sparrow) would responsively utilize the newly emptied acoustic space. The birds reacted by generating higher performance songs at lower amplitudes, effectively optimizing the distance and salience of communication (Derryberry et al., 2020). Omnipresent anthropogenic noise is also one of the most hazardous forms of pollution in aquatic ecosystems. This includes sounds produced by human activity such as commercial shipping, oil exploration, construction activities, military and mapping sonars (Hildebrand, 2009). There was a significant reduction in ocean ambient noise during the pandemic. A study was conducted during the first quarter of 2020 in both the deep ocean and inland waters of Canada's Pacific coast using the near real-time ocean sensing networks North-East Pacific Time-series Undersea Networked Experiments (NEPTUNE) and Victoria Experimental Network Under the Sea (VENUS). The NEPTUNE observatory reported an average reduction of $1.5 \mathrm{~dB}$ in the mean weekly noise power spectral density at $100 \mathrm{~Hz}$ year-over-year. The overall change in power at $100 \mathrm{~Hz}$ showed a drop of $2.7-7.1 \mathrm{~dB}$ on both the Central and East nodes of the VENUS observatory, respectively, using the time series of the difference in median weekly power (Thomson \& Barclay, 2020). 
Many sea creatures like Baleens whales use sounds in the water to navigate, hunt for food, and communicate (Tyack \& Clark, 2000). A study showed that there was an association between noise reduction and decreased baseline levels of stress-related faecal hormone metabolites (glucocorticoids) in North Atlantic right whales (Eubalaena glacialis). This might result in a recovery of the endangered right whale population due to less noise pollution (Rolland et al., 2012). Zooplankton and tens of thousands of fish species, which are sensitive to noises, may also have had higher chances to go through their spawning cycle and flourish due to the decline of underwater ocean noise during the COVID-19 pandemic.

Companies and vehicle manufacturers should increase their efforts to design automobiles that emit less noise. Noise barriers can also be installed since they are effective at blocking the direct flow of sound waves from the highway or other busy regions to houses, businesses, and natural habitats. Much can be done to lessen the noise produced from shipping and transport. Reducing nighttime traffic, proper terminal allocation, reducing the airflow of fans, lowering the energy consumption of ships, and utilizing an onshore power supply, particularly at night, appear to be viable options (Čurović et al., 2021). Additional metrics defining human activities that generate noise need to be developed so that people have a better understanding of their area's noise environment. Similar to weather stations established to gather data for weather forecasts, additional noise indicators may need to be set up at various places to measure the level of noise pollution in order to provide information to the public about noise pollution, an invisible danger that is often neglected.

\section{Planetary health and zoonotic disease}

Of note, there were enormous environmental benefits as a result of the COVID-19 pandemic lockdown that could have paradoxically reduced the number of morbidities and mortalities due to anthropogenic pollution. Unfortunately, the resumption of large industrial activities will likely reverse all these environmental improvements.

The Economist Intelligence Unit measured the readiness to confront climate change of the world's 82 largest economies. Due to the impact of higher temperatures and more severe weather events, the climate change Resilience Index showed that there would be a $3 \%$ drop in the global gross domestic product by 2050 with developing nations having poorer resilience than richer ones. By mid-century, climate change could result in direct costs to the world economy of $\$ 7.9$ trillion as intensified droughts, floods, and crop failures impede development and endanger infrastructure (Economist Intelligence Unit, 2019). According to the WHO, the social and environmental determinants of health, like clean air and water, adequate food, and secure shelter are affected by climate change. An increase of about 250,000 additional deaths are expected each year from malnutrition, malaria, diarrhoea, and heat stress between 2030 and 2050 (World Health Organization, 2018). Therefore, no party should ignore climate change or downplay the consequences of it.

Anthrax, another zoonotic disease, severely affected reindeer herds in Siberia and led to an outbreak in 2016. It was reported that the pathogen was released from infected carcasses in permafrost soil as the ice thawed (Stella et al., 2020). Anthrax may not be the only infectious disease lurking in the ice. There is speculation that there are tens of thousands of carcasses with infectious disease preserved in the frozen soil. For instance, victims of the 1918 Spanish flu were found in the permafrost with groundpenetrating radar (Davis et al., 2000). As global warming continues to increase the temperature of the planet, we may experience the re-emergence of pathogens that were already eradicated in the past or that are new to us and which could serve as serious health threats to both animals and human beings. Regrettably, the positive changes from the COVID-19 pandemic lockdown will not be permanent and will not mitigate climate change and environmental issues. However, it surely serves as a practical lesson to the world that environmental degradation and climate change are still reversible and that it is possible to take drastic measures to achieve the Sustainable Development Goals of the United Nations for the long-term environmental health of the planet. This includes measures like extensive utilisation of clean energy and changing our sources and means of producing food. Food production accounts for approximately $26 \%$ of global greenhouse gas emissions and the largest contribution to that is from livestock and fisheries (Poore \& Nemecek, 2018). The WHO Director- 
General, Dr. Tedros Adhanom Ghebreyesus, stated that the COVID-19 outbreak will not be the last pandemic and without addressing climate change and animal welfare, efforts to improve human health are hopeless (Millard, 2020). While there is still time for us to repair much of the environmental damage that has already been done, world leaders should revisit and revise their national policies to emphasize the urgency of environmental matters. With that and other measures, such as addressing animal welfare, hopefully, another COVID-19-like pandemic can be averted.

\section{Limitation of the study and recommendation}

We acknowledge that since the study only focused on the positive global environmental impacts of the COVID-19 pandemic lockdown, this may result in some inherent bias. Therefore, regardless of the positive impacts on the environment discussed above, we recognise that there were also negative consequences on planetary health during the COVID-19 lockdown. There is mounting evidence that indoor air pollution is a severe threat to human health (Mannucci \& Franchini, 2017). Indoor activities from household or workstation tasks all contribute to indoor pollution (Amoatey et al., 2020). These emissions must remain within acceptable levels and should be monitored on a regular basis in order to implement effective pollution mitigation strategies (Agarwal et al., 2021). There were also studies that showed a positive association of air pollutants with increasing cases of COVID-19 (Coker et al., 2020; Wu et al., 2020). This is particularly important because, during the pandemic lockdown, people were forced to stay indoors. Therefore, measures like ensuring proper ventilation are critical to offering a healthy indoor environment for the safety of inhabitants and at the same time, to reduce the spread of the disease (Agarwal et al., 2021). While many places experienced improved water quality in natural resources, wastewater treatment plants reported a higher level of organic load and chemical contaminants due to the increased use of sanitisers, disinfectants, and antibiotics (Elsaid et al., 2021). Wastewater had to be properly treated before being discharged into biological treatment facilities and subsequently into water bodies (Leonhauser et al., 2014). In addition, wastewater can also capture viruses like COVID-19 that shed during personal hygiene and are present in the excretion or discharge from human beings, such as from the mouth cavity, upper respiratory tract, faeces, and urine (Cheung et al., 2020). Wastewater analysis was shown to be sensitive to viral testing and cost-effective and thus, could be employed as a surveillance tool for epidemiological studies. When compared to individual COVID-19 testing, wastewater analysis is clearly less invasive, simpler, and less expensive. It is an important component in effectively combatting COVID-19 and in improving our preparation in the case of viral re-emergence (Randazzo et al., 2020). On the other hand, there was an unavoidable increase in the use of personal protective equipment, such as gloves, masks, etc., that directly increased the amount of medical waste. For instance, in Wuhan city, China, the epicentre of COVID-19, there was an extra 200 tons of medical waste in a single day on 24th February 2020 (Bashir et al., 2020). Hence, effective and stringent waste management measures must be implemented before another major source of environmental pollution arises.

In return, the beneficial environmental effects also resulted in some feedback loop effects on the COVID19. For instance, it was hypothesized that the COVID19 virus can bind to PM and increase the chance of survival of the virus in the atmosphere under conditions of atmospheric stability (McNeill, 2020). If proven, the spread of the coronavirus could be curbed with improved air quality. There is also a possibility that healthy or active soil might serve as a medium to halt the spread of COVID-19. Viruses, when in contact with soil and its clay fractions or particles (either kaolinite or most preferably bentonite), will be weakened and controlled naturally. This may help to slow down the rapid spread of COVID-19. A further systematic investigation is required to study and validate the association (Mishra et al., 2020).

\section{Conclusions}

While the negative impacts from the pandemic cannot be ignored, the COVID-19 crisis has presented an extraordinary situation with substantial environmental gain. The positive impacts on global environmental and planetary health that the COVID-19 pandemic lockdown brought about are noteworthy, even if they 
will be quickly erased as the world goes from lockdowns to a gradual return to normalcy. Therefore, behavioural changes such as adopting a lifestyle that reduces carbon footprint are needed to make a positive impact on the environment. Even though environmental health is improving, efforts to mitigate the longlasting and ongoing environmental pollution remains a herculean task. Ideally, measures should be taken to lengthen the positive impacts we experienced from the pandemic in the hope that the earth's self-recuperative properties will carry on for the long term. At the same time, observations and knowledge gained of the positive environmental impacts of the pandemic should be documented and used to help make comprehensive evidence-based public policies for the survival of humankind. World leaders should consider the national policy changes necessary to ensure continuity of as many of the positive environmental impacts from the COVID-19 pandemic lockdown as possible. Those changes would also serve to lessen the likelihood of another zoonotic calamity.

Acknowledgements We would like to thank the DirectorGeneral of Health Malaysia for his permission to publish this article.

Authors' contributions Conceptualization, H.C.L., I.L., A.S.H.C.; methodology, H.C.L., I.L., A.S.H.C., and K.H.A.; validation, H.C.L., L.C.M., and K.H.A..; formal analysis, H.C.L.,K.W.G., L.C.M., and K.H.A.; investigation, H.C.L., I.L., A.S.H.C., K.W.G., L.C.M., and K.H.A.; resources, H.C.L., I.L., A.S.H.C., K.W.G., L.C.M., and K.H.A.; data curation, H.C.L., and K.H.A.; writing-original draft preparation, H.C.L., I.L., L.C.M., and K.H.A.; writing-review and editing, H.C.L., I.L., A.S.H.C., K.W.G., L.C.M., and K.H.A.; supervision, I.L., A.S.H.C., L.C.M., and K.H.A.; project administration, H.C.L., I.L., and A.S.H.C.; funding acquisition, K.H.A.

Funding No funding was received for conducting this study.

\section{Declarations}

Conflicts of interest The authors have no conflicts of interest to declare that are relevant to the content of this article.

Consent for publication All authors have read and agreed to the published version of the manuscript.

Ethical approval Medical Review \& Ethics Committee (MREC), Ministry of Health Malaysia granted the exemption.

\section{References}

Agarwal, N., Meena, C. S., Raj, B. P., Saini, L., Kumar, A., Gopalakrishnan, N., Kumar, A., Balam, N. B., Alam, T., Kapoor, N. R., \& Aggarwal, V. (2021). Indoor air quality improvement in COVID-19 pandemic: Review. Sustainable Cities and Society. https://doi.org/10.1016/j.scs.2021. 102942

Akimoto, H. (2003). Global air quality and pollution. Science, 302(5651), 1716-1719. https://doi.org/10.1126/science. 1092666

Amoatey, P., Omidvarborna, H., Baawain, M. S., \& Al-Mamun, A. (2020). Impact of building ventilation systems and habitual indoor incense burning on SARS-CoV-2 virus transmissions in Middle Eastern countries. Science of the Total Environment. https://doi.org/10.1016/j.scitotenv. 2020.139356

Asensio, C., Pavón, I., \& de Arcas, G. (2020). Changes in noise levels in the city of Madrid during COVID-19 lockdown in 2020. Journal of the Acoustical Society of America, 148(3), 1748. https://doi.org/10.1121/10.0002008

Aydın, S., Nakiyingi, B. A., Esmen, C., Güneysu, S., \& Ejjada, M. (2020). Environmental impact of coronavirus (COVID19) from Turkish perceptive. Environment, Development and Sustainability. https://doi.org/10.1007/s10668-02000933-5

Bashir, M. F., Ma, B., \& Shahzad, L. (2020). A brief review of socio-economic and environmental impact of Covid-19. Air Quality, Atmosphere \& Health, 13(12), 1403-1409. https://doi.org/10.1007/s11869-020-00894-8

Berglund, B., Lindvall, T., \& Schwela, D. H. (1999). Guidelines for community noise. Retrieved 1 Feb 2021 from https:// www.who.int/docstore/peh/noise/Comnoise-1

Cheung, K. S., Hung, I. F. N., Chan, P. P. Y., Lung, K. C., Tso, E., Liu, R., Ng, Y. Y., Chu, M. Y., Chung, T. W. H., Tam, A. R., Yip, C. C. Y., Leung, K. H., Fung, A. Y., Zhang, R. R., Lin, Y., Cheng, H. M., Zhang, A. J. X., To, K. K. W., Chan, K. H., ... Leung, W. K. (2020). Gastrointestinal manifestations of SARS-CoV-2 infection and virus load in fecal samples from a Hong Kong cohort: Systematic review and meta-analysis. Gastroenterology, 159(1), 81-95. https://doi.org/10.1053/j.gastro.2020.03.065

Child, D. (2020). The positive impacts on the environment since the coronavirus lockdown began. Evening Standard. Retrieved 1 Feb 2021 from https://www.standard.co.uk/ news/world/positive-impact-environment-coronaviruslockdown-a4404751.html

Clair, T. A., \& Hindar, A. J. E. R. (2005). Liming for the mitigation of acid rain effects in freshwaters: A review of recent results. Environmental Reviews, 13(3), 91-128. https://doi.org/10.1139/a05-009

Clay, K., \& Muller, N. Z. (2019). Recent increases in air pollution: Evidence and implications for mortality. National Bureau of Economic Research. https://doi.org/10.3386/ w26381

Cohen, A. J., Brauer, M., Burnett, R., Anderson, H. R., Frostad, J., Estep, K., Balakrishnan, K., Brunekreef, B., Dandona, L., \& Dandona, R. (2017). Estimates and 25-year trends of the global burden of disease attributable to ambient air pollution: an analysis of data from the Global Burden of 
Diseases Study 2015. The Lancet, 389(10082), 1907-1918. https://doi.org/10.1016/S0140-6736(17)30505-6

Coker, E. S., Cavalli, L., Fabrizi, E., Guastella, G., Lippo, E., Parisi, M. L., Pontarollo, N., Rizzati, M., Varacca, A., \& Vergalli, S. (2020). The effects of air pollution on COVID19 related mortality in Northern Italy. Environmental and Resource Economics, 76(4), 611-634. https://doi.org/10. 1007/s10640-020-00486-1

Čurović, L., Jeram, S., Murovec, J., Novaković, T., Rupnik, K., \& Prezelj, J. (2021). Impact of COVID-19 on environmental noise emitted from the port. Science of The Total Environment. https://doi.org/10.1016/j.scitotenv.2020. 144147

Davis, J. L., Heginbottom, J. A., Annan, A. P., Daniels, R. S., Berdal, B. P., Bergan, T., Duncan, K. E., Lewin, P. K., Oxford, J. S., Roberts, N., Skehel, J. J., \& Smith, C. R. (2000). Ground penetrating radar surveys to locate 1918 Spanish flu victims in permafrost. Journal of Forensic Sciences, 45(1), 68-76.

Derryberry, E. P., Phillips, J. N., Derryberry, G. E., Blum, M. J., \& Luther, D. (2020). Singing in a silent spring: Birds respond to a half-century soundscape reversion during the COVID-19 shutdown. Science, 370(6516), 575-579. https://doi.org/10.1126/science.abd5777

Dutheil, F., Baker, J. S., \& Navel, V. (2020). COVID-19 as a factor influencing air pollution? Environmental Pollution. https://doi.org/10.1016/j.envpol.2020.114466

Dutta, V., Dubey, D., \& Kumar, S. (2020). Cleaning the River Ganga: Impact of lockdown on water quality and future implications on river rejuvenation strategies. Science of The Total Environment. https://doi.org/10.1016/j. scitotenv.2020.140756

Economist Intelligence Unit. (2019). Global economy will be 3 percent smaller by 2050 due to lack of climate resilience. Retrieved 1 Feb 2021 from https://www.eiu.com/n/globaleconomy-will-be-3-percent-smaller-by-2050-due-to-lackof-climate-resilience/

Elsaid, K., Olabi, V., Sayed, E. T., Wilberforce, T., \& Abdelkareem, M. A. (2021). Effects of COVID-19 on the environment: An overview on air, water, wastewater, and solid waste. Journal of Environmental Management. https://doi.org/10.1016/j.jenvman.2021.112694

Fan, Y. V., Jiang, P., Hemzal, M., \& Klemeš, J. J. (2020). An update of COVID-19 influence on waste management. The Science of the Total Environment, 754, 142014-142014. https://doi.org/10.1016/j.scitotenv.2020.142014

FAO. (2020). How is COVID-19 affecting the fisheries and aquaculture food systems https://doi.org/10.4060/ ca8637en

Fust, W. (2010). Human impact report: Climate change-the anatomy of a silent crisis. Retrieved 1 Feb 2021 from https://www.preventionweb.net/files/9668_ humanimpactreport 1

Gautam, S. (2020a). COVID-19: Air pollution remains low as people stay at home. Air Quality, Atmosphere \& Health, 13(7), 853-857. https://doi.org/10.1007/s11869-02000842-6

Gautam, S. (2020b). The influence of COVID-19 on Air quality in India: A boon or inutile. Bulletin of Environment Contamination and Toxicology, 104(6), 724-726. https://doi. org/10.1007/s00128-020-02877-y
Geggel, L. (2020). Baby leatherback sea turtles thriving due to COVID-19 beach restrictions. Live Science. Retrieved 1 Feb 2021 from https://www.livescience.com/leatherbacksea-turtle-babies-thrive-covid-19-pandemic.html

Geravandi, S., Takdastan, A., Zallaghi, E., Vousoghi Niri, M., Mohammadi, M. J., Saki, H., \& Naiemabadi, A. (2015). Noise pollution and health effects. Jundishapur Journal of Health Sciences, 7(1).

Grange, S. K., Lee, J. D., Drysdale, W. S., Lewis, A. C., Hueglin, C., Emmenegger, L., \& Carslaw, D. C. (2020). COVID-19 lockdowns highlight a risk of increasing ozone pollution in European urban areas. Atmospheric Chemistry and Physics Discussions, 2020, 1-25. https://doi.org/10.5194/acp2020-1171

Hart, O. E., \& Halden, R. U. (2020). Computational analysis of SARS-CoV-2/COVID-19 surveillance by wastewaterbased epidemiology locally and globally: Feasibility, economy, opportunities and challenges. Science of The Total Environment, 730, 138875.

Helm, D. (2020). The environmental impacts of the coronavirus. Environmental and Resource Economics, 76(1), 21-38. https://doi.org/10.1007/s10640-020-00426-z

Hildebrand, J. A. (2009). Anthropogenic and natural sources of ambient noise in the ocean. Marine Ecology Progress Series, 395, 5-20. https://doi.org/10.3354/meps08353

Huang, C., Wang, T., Niu, T., Li, M., Liu, H., \& Ma, C. (2021). Study on the variation of air pollutant concentration and its formation mechanism during the COVID-19 period in Wuhan. Atmospheric Environment. https://doi.org/10. 1016/j.atmosenv.2021.118276

Huckelba, A. L., \& Van Lange, P. A. (2020). The silent killer: Consequences of climate change and how to survive past the year 2050. Sustainability. https://doi.org/10.3390/ su12093757

IQAir. (2019). World's most polluted cities 2019 (PM2.5). Retrieved 1 Feb 2021 from https://www.iqair.com/worldmost-polluted-cities

Ising, H., \& Kruppa, B. (2004). Health effects caused by noise: Evidence in the literature from the past 25 years. Noise and Health 6(22): 5-13. https://www.noiseandhealth.org/ article. asp?issn $=1463-1741$; year=2004; volume $=6$; issue $=$ 22 ; page $=5$; epage $=13$; aulast $=$ Ising

Jribi, S., Ben Ismail, H., Doggui, D., \& Debbabi, H. (2020). COVID-19 virus outbreak lockdown: What impacts on household food wastage? Environment, Development and Sustainability. https://doi.org/10.1007/s10668-020-00740$\mathrm{y}$

Korten, T. (2020). With bats stuck in harbor because of COVID19, will fish bounce back? Smithsonian Magazine. Retrieved 1 Feb 2021 from https://www.smithsonianmag. com/science-nature/fish-stop-covid-19-180974623/

Lecocq, T., Hicks, S. P., Van Noten, K., Van Wijk, K., Koelemeijer, P., De Plaen, R. S., Massin, F., Hillers, G., Anthony, R. E., \& Apoloner, M.-T. (2020). Global quieting of highfrequency seismic noise due to COVID-19 pandemic lockdown measures. Science, 369(6509), 1338-1343. https://doi.org/10.1126/science.abd2438

Lenzen, M., Li, M., Malik, A., Pomponi, F., Sun, Y. Y., Wiedmann, T., Faturay, F., Fry, J., Gallego, B., Geschke, A., \& Gómez-Paredes, J. (2020). Global socio-economic losses and environmental gains from the Coronavirus 
pandemic. PloS one. https://doi.org/10.1371/journal.pone. 0235654

Leonhauser, J., Pawar, J., Birkenbeul, U., Ranade, V., \& Bhandari, V. (2014). Novel technologies for the elimination of pollutants and hazardous substances in the chemical and pharmaceutical industries. Industrial Wastewater Treatment, Recycling Reuse

Lombrana, L. M. (2020). With fishing fleets tied up, marine life given a chance to recover. Bloomberg. Retrieved $1 \mathrm{Feb}$ 2021 from https://www.bloombergquint.com/onweb/withfishing-fleets-tied-up-marine-life-has-a-chance-to-recover

López-Feldman, A., Heres, D., \& Marquez-Padilla, F. (2021). Air pollution exposure and COVID-19: A look at mortality in Mexico City using individual-level data. The Science of the Total Environment. https://doi.org/10.1016/j.scitotenv. 2020.143929

Lovrić, M., Pavlović, K., Vuković, M., Grange, S. K., Haberl, M., \& Kern, R. (2021). Understanding the true effects of the COVID-19 lockdown on air pollution by means of machine learning. Environmental Pollution (Barking, Essex: 1987) https://doi.org/10.1016/j.envpol.2020. 115900

Mannucci, P. M., \& Franchini, M. (2017). Health effects of ambient air pollution in developing countries. International Journal of Environmental Research and Public Halth. https://doi.org/10.3390/ijerph14091048

Mariani, G., Cheung, W. W., Lyet, A., Sala, E., Mayorga, J., Velez, L., Gaines, S. D., Dejean, T., Troussellier, M., \& Mouillot, D. (2020). Let more big fish sink: Fisheries prevent blue carbon sequestration-half in unprofitable areas. Science Advances. https://doi.org/10.1126/sciadv. abb4848

McNeill, V. F. (2020). COVID-19 and the air we breathe. ACS Earth \& Space Chemistry. https://doi.org/10.1021/ acsearthspacechem.0c00093

Millard, R. (2020). WHO chief: COVID won't be last pandemic; 'short-sighted' stance dooms our health. Retrieved 1 Feb 2021 from https://www.timesofisrael.com/who-chiefwarns-covid-19-pandemic-wont-be-the-last/

Mirzaei, R., Ansari, M. A., Mohammadi, M., Rakhshani, F., \& Salmanpor, M. (2012). Noise pollution in zahedan and residents'knowledge about noise pollution. Health Scope, 1(1), 3-6. https://doi.org/10.5812/jhs.4544

Mishra, B. B., Roy, R., Singh, S. K., Sharma, S. K., Prasad, B. D., Choudhary, S. K., Jha, A. K., \& Sahni, S. (2020). Preventive measures against transmission and multiplication of COVID-19 following the simple natural laws with soil clay, and biodiversity. Communities, 5(2), 622-632.

Mitra, P., Misra, S., \& Sharma, P. (2020). COVID-19 Pandemic in India: What lies ahead. Indian Journal of Clinical Biochemistry. https://doi.org/10.1007/s12291-020-00886-6

Muhammad, S., Long, X., \& Salman, M. (2020). COVID-19 pandemic and environmental pollution: A blessing in disguise? Science of The Total Environment. https://doi.org/ 10.1016/j.scitotenv.2020.138820

Nishan, D. (2020). Six places where oceans, rivers and Marine life have rebounded during the coronavirus pandemic. Forbes. Retrieved 1 Feb 2021 from https://www.forbes. com/sites/nishandegnarain/2020/05/16/six-places-whereoceans-rivers-and-marine-life-have-rebounded-duringthe-coronavirus-pandemic/?sh=141cd893fb05
Orlowski, A. (2020). Small-scale fishermen suffering significantly from COVID-19 pandemic. SeafoodSource. Retrieved 5 Jan 2021 from https://www.seafoodsource. com/news/supply-trade/small-scale-fishermen-sufferingsignificantly-from-covid-19-pandemic

Ormaza-González, F., \& Castro-Rodas, D. (2020). COVID-19 Impacts on beaches and coastal water pollution: Management proposals post-pandemic https://doi.org/10.20944/ preprints202006.0186.v1

Ouhsine, O., Ouigmane, A., Layati, E., Aba, B., Isaifan, R., \& Berkani, M. (2020). Impact of COVID-19 on the qualitative and quantitative aspect of household solid waste. Global Journal of Environmental Science Management, 6(Special Issue (Covid-19)): 41-52 https://doi.org/10. 22034/GJESM.2019.06.SI.05

Poore, J., \& Nemecek, T. J. S. (2018). Reducing food's environmental impacts through producers and consumers. Science, 360(6392), 987-992. https://doi.org/10.1126/ science.aaq0216

Qarani, A. S. (2020). Potential impact of COVID-19 pandemic lockdown on environmental parameters. Recycling and Sustainable Development, 13(1), 49-61. https://doi.org/10. 5937/ror2001049A

Randazzo, W., Cuevas-Ferrando, E., Sanjuán, R., DomingoCalap, P., \& Sánchez, G. (2020). Metropolitan wastewater analysis for COVID-19 epidemiological surveillance. International Journal of Hygiene and Environmental Health. https://doi.org/10.1016/j.ijheh.2020.113621

Rolland, R. M., Parks, S. E., Hunt, K. E., Castellote, M., Corkeron, P. J., Nowacek, D. P., Wasser, S. K., \& Kraus, S. D. (2012). Evidence that ship noise increases stress in right whales. Proceedings of the Royal Society B: Biological Sciences, 279(1737), 2363-2368.

Rutz, C., Loretto, M.-C., Bates, A. E., Davidson, S. C., Duarte, C. M., Jetz, W., Johnson, M., Kato, A., Kays, R., Mueller, T., Primack, R. B., Ropert-Coudert, Y., Tucker, M. A., Wikelski, M., \& Cagnacci, F. (2020). COVID-19 lockdown allows researchers to quantify the effects of human activity on wildlife. Nature Ecology \& Evolution, 4(9), 1156-1159. https://doi.org/10.1038/s41559-020-1237-z

Saadat, S., Rawtani, D., \& Hussain, C. M. (2020). Environmental perspective of COVID-19. Science of the Total Environment. https://doi.org/10.1016/j.scitotenv.2020. 138870

Sarkodie, S. A., \& Owusu, P. A. (2020). Impact of meteorological factors on COVID-19 pandemic: Evidence from top 20 countries with confirmed cases. Environmental Research. https://doi.org/10.1016/j.envres.2020.110101

Screen, J. A., \& Deser, C. (2019). Pacific Ocean variability influences the time of emergence of a seasonally ice-free Arctic Ocean. Geophysical Research Letters, 46(4), 2222-2231. https://doi.org/10.1029/2018GL081393

Shah, J. N., Shah, J., \& Shah, J. (2020). Quarantine, isolation and lockdown: In context of COVID-19. Journal of Patan Academy of Health Sciences, 7(1), 48-57. https://doi.org/ 10.3126/jpahs.v7i1.28863

Shakil, M. H., Munim, Z. H., Tasnia, M., \& Sarowar, S. (2020). COVID-19 and the environment: A critical review and research agenda. Science of the Total Environment. https:// doi.org/10.1016/j.scitotenv.2020.141022 
Singh, S., \& Singh, M. (2020). Soil Pollution and Human Health. In Plant Responses to Soil Pollution, Springer, (pp. 205-220).

Somala, S. N. (2020). Seismic noise changes during COVID-19 pandemic: A case study of Shillong, India. Natural Hazards (dordrecht, Netherlands). https://doi.org/10.1007/ s11069-020-04045-1

Sordello, R., Ratel, O., Flamerie De Lachapelle, F., Leger, C., Dambry, A., \& Vanpeene, S. (2020). Evidence of the impact of noise pollution on biodiversity: A systematic map. Environmental Evidence, 9(1), 20. https://doi.org/10. 1186/s13750-020-00202-y

Stella, E., Mari, L., Gabrieli, J., Barbante, C., \& Bertuzzo, E. (2020). Permafrost dynamics and the risk of anthrax transmission: A modelling study. Scientific Reports, 10(1), 16460. https://doi.org/10.1038/s41598-020-72440-6

Straka, W., Kondragunta, S., Wei, Z., Zhang, H., Miller, S. D., \& Watts, A. (2021). Examining the economic and environmental impacts of COVID-19 using earth observation data. Remote Sensing. https://doi.org/10.3390/rs13010005

Thomson, D. J., \& Barclay, D. R. (2020). Real-time observations of the impact of COVID-19 on underwater noise. Journal of the Acoustical Society of America, 147(5), 3390-3396. https://doi.org/10.1121/10.0001271

Tianna, M. (2020). A time for healing: Hawaii's coral reefs rebound during COVID-19. Retrieved 1 Feb 2021 from https://hitchcockproject.org/hawaii-coral-reefs-healing/

Tsangaras, K., \& Greenwood, A. D. (2018). Paleovirology: Viral sequences from historical and ancient DNA. In Paleogenomics, Springer, (pp. 139-162).

Tyack, P. L., \& Clark, C. W. (2000). Communication and acoustic behavior of Dolphins and Whales (Hearing by Whales and Dolphins. Springer Handbook of Auditory Research), vol. 12, (Ed.). Springer, New York, NY. https:// doi.org/10.1007/978-1-4612-1150-1_4

Upadhyay, V. (2020). Lockdown effect: Ganga water fit for drinking after decades, say experts. Retrieved 1 Feb 2021 from https:/www.newindianexpress.com/nation/2020/ may/08/lockdown-effect-ganga-water-fit-for-drinkingafter-decades-say-experts-2140622.html
Van Donkelaar, A., Martin, R. V., Brauer, M., Kahn, R., Levy, R., Verduzco, C., \& Villeneuve, P. J. (2010). Global estimates of ambient fine particulate matter concentrations from satellite-based aerosol optical depth: Development and application. Environmental health perspectives, 118(6), 847-855. https://doi.org/10.1289/ehp.0901623

Wang, Q., Lu, M., Bai, Z., \& Wang, K. (2020). Coronavirus pandemic reduced China's $\mathrm{CO} 2$ emissions in short-term, while stimulus packages may lead to emissions growth in medium-and long-term. Applied Energy. https://doi.org/ 10.1016/j.apenergy.2020.115735

Wang, Q., \& Su, M. (2020). A preliminary assessment of the impact of COVID-19 on environment-A case study of China. Science of The Total Environment. https://doi.org/ 10.1016/j.scitotenv.2020.138915

World Health Organization. (2018). Climate change and health. Retrieved 1 Feb 2021 from https://www.who.int/newsroom/fact-sheets/detail/climate-change-and-health

Wu, X., Nethery, R. C., Sabath, B. M., Braun, D., \& Dominici, F. (2020). Exposure to air pollution and COVID-19 mortality in the United States. medRxiv.

Xiao, H., Eilon, Z. C., Ji, C., \& Tanimoto, T. (2020). COVID-19 societal response captured by seismic noise in China and Italy. Seismological Society of America, 91(5), 2757-2768. https://doi.org/10.1785/0220200147

You, Y., \& Pan, S. (2020). Urban vegetation slows down the spread of coronavirus disease (COVID-19) in the United States. Geophysical Research Letters, 47(18), e2020GL089286. https://doi.org/10.1029/2020GL089286

Zambrano-Monserrate, M. A., Ruano, M. A., \& Sanchez-Alcalde, L. (2020). Indirect effects of COVID-19 on the environment. The Science of the Total Environment, 728, 138813-138813. https://doi.org/10.1016/j.scitotenv.2020. 138813

Publisher's Note Springer Nature remains neutral with regard to jurisdictional claims in published maps and institutional affiliations. 